\title{
SOUTH CHINA KARST 1999 PRELIMINARY RESEARCH IN YUNNAN
}

\author{
JUŽNOKITAJSKI KRAS 1999 \\ PREDHODNE RAZISKAVE V YUNNANU
}

JANJA KOGOVŠEK ${ }^{1} \&$ ANDREJ KRANJC ${ }^{1} \&$ TADEJ SLABE ${ }^{1} \&$ STANKA ŠEBELA $^{1}$

\footnotetext{
${ }^{1}$ Karst Research Institute ZRC SAZU, Titov trg 2, SI-6230 POSTOJNA, SLOVENIA
} 


\section{Janja Kogovšek \& Andrej Kranjc \& Tadej Slabe \& Stanka Šebela: Južnokitajski kras 1999, predhodne} raziskave v Yunnanu

Že od leta 1995 sodelujejo sodelavci IZRK ZRC SAZU na slovensko-kitajskih projektih s področja krasoslovja. V letu 1998 so rezultate raziskav objavili v knjigi "South China Karst". Tudi v letu 1999 so raziskave opravljali v Yunnanu, in sicer v lunanskem osrednjem "shilinu" (kamnitem gozdu) kot tudi v turistično manj znanih "shilinih". Poleg tega so spoznavali značilnosti stolpastega krasa okoli krajev Babao in Puzhehei (jugovzhodni Yunnan).

Ključne besede: geologija, hidrologija, geomorfologija, speleologija, stolpasti kras, shilin, Yunnan, Kitajska.

\section{Abstract \\ UDC: 551.44(510)“1999” \\ Janja Kogovšek \& Andrej Kranjc \& Tadej Slabe \& Stanka Šebela: South China Karst 1999, Preliminary research in Yunnan}

From 1995 researchers from Karst Research Institute ZRC SAZU are working on slovene-chinese karstological projects. In 1998 their studies were published in the book "South China Karst". Also in the year 1999 researches took place in Yunnan, that's in central Lunan shilin (stone forest) as well as in less touristically known shilins. Beside this they have been recognising characteristics of cone and tower karst in the regions of Babao and Puzhehei.

Key words: geology, hydrology, geomorphology, speleology, tower karst, shilin, Yunnan, China. 


\section{INTRODUCTION}

Karstologists from the Yunnan Geographic Institute and the collaborators of the Karst Research Institute ZRC SAZU have been co-operating successfully for a number of years. The findings of investigations carried out to date have also been published in the book South China Karst. The Chinese and Slovene Ministries for Science have financially supported the Classic and Yunnan karst comparison project. This is our report on the first part of the fieldwork carried out for the project. We have continued to investigate the Yunnan Stone Forest and the caves beneath it, and have initiated research into the tower (fenglin) karst in Quibei and considered the possibility of expanding the investigation to the south-eastern part of the province, to the extremely interesting cone (fengzong) karst with numerous caves. In the future, we plan to investigate mountain karst in the northern part of the province.

\section{Short description of the terrain}

One of the parts of China with the highest percentage of karst is the province of Yunnan, which has $103000 \mathrm{~km}^{2}$ of karst, that is about the quarter of its territory. Karst exists practically in all parts of the province, but the most condensed areas are in the eastern and south-eastern parts. Some of the counties (xian) are lying completely on the karst, as for example Guangnan, where the karst represents more than $97 \%$ of the territory. That is why we studied, together with the colleagues from the Geographical institute of Kunming, besides "shilins" (stone forests) in the Lunan county (prefecture Kunming), the karst just in these parts of the province.

South-eastern Yunnan karst remind us to the Dinaric karst: it is developed in thick limestone formations (mainly of Palaeozoic and Triassic age), in some places covered by thick beds of younger impermeable sediments of Eocene age, similar to our flysch: conglomerates sandstone, and specially thick cover of loam and clay (Song \& Liu 1989). Karst surface with thick impermeable cover remind us the most to Bela krajina karst in Slovenia.

But there are differences too. Water concentrate already on the surface (here the karst is not a "riddle") and there are often ponors in the bottom of the dolines, while their slopes are heavily eroded. Piezometric level is relatively near the surface, therefore the depressions are often flooded and underground streams are shallow under the surface. And specially different are surface features.

Among them two types of karst surface are the most important: "shilin" (stone forest) and tower or cone (fenglin or fengcong in Chinese) karst. In this case it is not a question of singular morphological feature, but of the special type of karst we do not have in Europe. Such type of karst is known from some parts of subtropical and tropical belt, it is specially extensive in China, including the province of Yunnan.

Besides Shilin "stone forest" near the village Shilin (former county of Lunan, today also Shilin), which is the origin of the proposed scientific term "shilin", there is more shilins in the county of Shilin. Some are arranged for the tourist visit (Naigu Shilin for example), and some are in "natural state". We worked in some of the last mentioned too. The best examples of tower karst are in the south-eastern part of the province. There we visited two regions with such a karst, Babao and Puzhehei. 
Geology-Tectonics - Investigation of caves in the direct vicinity of central Shilin (the Stone Forest)

In the direct vicinity of the central Lunan Shilin, we structure-geologically mapped three karstic caves (Gibailongdong, Dieyunyandong, and Dziyundong). In the Naigu Shilin, which is 20 kilometres to the east of the central Shilin, we also mapped Baiyundong Cave. All four caves are prepared for and open to visitors. In our work, we used cave plans by researchers from the Yunnan Institute for Geography (Liu Hong, Chen Xiaoping, and Huang Chuxing). The main guiding principle of the research was the connection of geologic structural elements with the direction and development of cave passages. With this in mind, we mapped the cave passages in detail by measuring the directions and dips of the beds as well as of fractures and faults.

The basic statistic, giving the most frequent directions of passages (Fig. 1) at a distribution of intervals of 10 degrees and a population of 207, indicates that in the four geologically mapped caves, most passages $\left(23.7 \%\right.$ ) have developed in the direction of $\mathrm{N} 0-10^{\circ} \mathrm{W}$. The second most frequent direction of the passages is $\mathrm{N} 30-40^{\circ} \mathrm{W}(16 \%)$ and the third $\mathrm{N} 110-120^{\circ} \mathrm{E}(12.5 \%)$. The interval of confidence is $13.93^{\circ}$; the standard deviation is $5.76 \%$. The results represent the most frequent directions for a total of 1,478 metres of passages, which represent four caves.

A larger number of passages in Dziyundong cave differs from passages in the other three caves. Passages in the direction of $\mathrm{N} 30-40^{\circ} \mathrm{W}(47.1 \%)$ are most frequent; the direction $\mathrm{N} 10^{\circ} \mathrm{W}$ was found in only $6 \%$ of the passages. In two caves, the most frequent direction of the passages was $\mathrm{N} 0-10^{\circ} \mathrm{W}$, representing $47.8 \%$ in Dieyunyandong caves and $21.9 \%$ in Gibailongdong Cave.

Baiyundong Cave, located in the Naigu Shilin, has $34 \%$ of its passages in the direction of N110$120^{\circ} \mathrm{E}$, and, in second place, $30 \%$ in the direction of $\mathrm{N} 0-10^{\circ} \mathrm{W}$. The Naigu Shilin is formed in carbonate rock, included among the Qixia group. The rock is limestone, dolomitized limestone and Lower Permian chert. Qixia group carbonate rock is mostly thick-bedded to massive.

Through geological mapping, we found that many passages run along fractures. In this manner, we were able to follow a well-defined fracture in the ceiling of Dziyundong Cave running in a NWSE direction. The fractures in the cave ceiling are mainly subvertical. The main passage in Dieyunyandong, running in the direction $\mathrm{N} 0-10^{\circ} \mathrm{W}$, corresponds to the direction of the ceiling fracture. In most cases, the fracture is morphologically very distinct and only in rare cases can it be described as a fracture zone.

Passages in Gibailongdong are the most varied of the four caves. We observed at least four main passage directions: $\mathrm{N} 0-10^{\circ} \mathrm{W}(21.9 \%), \mathrm{N} 120-130^{\circ} \mathrm{E}(17 \%), \mathrm{N} 80-90^{\circ} \mathrm{E}(9 \%)$ and $\mathrm{N} 40-50^{\circ} \mathrm{W}$ (9\%). The passages, along distinct fractures, run in the directions of N0-10 ${ }^{\circ} \mathrm{W}$ and NW-SE.

In none of the four investigated caves did we find a classic fault at which we would be able to observe signs of tectonic movement. We determined a number of fractures that are morphologically similar to faults, but were unable to determine movement. In Dieyunyandong Cave, we followed such a fracture on the passage ceiling for 100 metres. The dip on the fracture varies between 70 and 90 degrees, and the direction changes from five to 10 degrees. The fracture is morphologically deep; during one period, vertical water percolation must have been very strong.

The results of surface geologic mapping of fractures in central Shilin from 1996 show that $20.79 \%$ of all fractures are oriented in the direction of $\mathrm{N} 30-45^{\circ} \mathrm{W}$, which corresponds to the second most frequent direction of the cave passages, $\mathrm{N} 30-40^{\circ} \mathrm{W}(16 \%)$. It is interesting that in central Shilin $5 \%$ of surface fractures lie in a $\mathrm{N} 0-15^{\circ} \mathrm{W}$ direction, while this is the most frequent direction of our cave passages. 


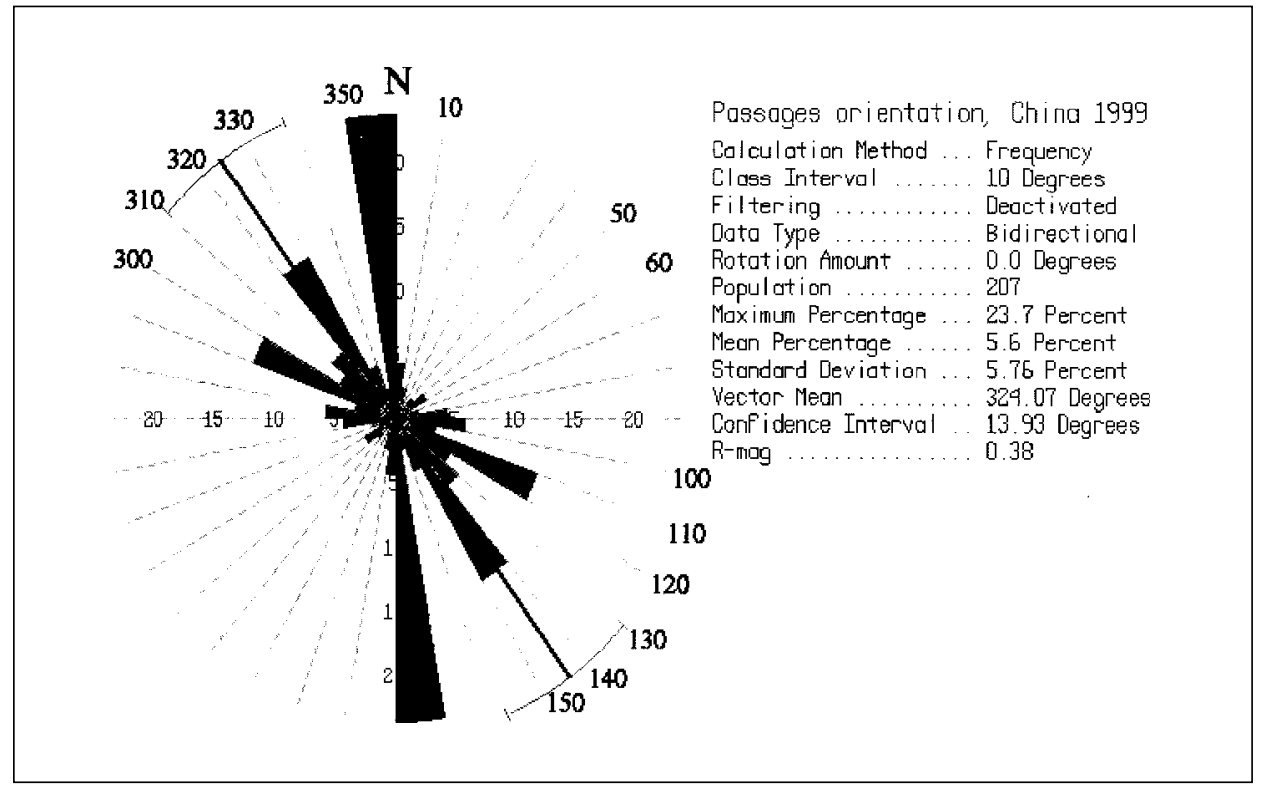

Fig. 1: Diagram-rosette of passage directions for Gibailongdong, Dieyunyandong, Dziyundong and Baiyundong Caves. The total length of the passages is 1,478 metres, the interval distribution 10 degrees.

Sl. 1: Diagram - rozeta smeri rovov za jame Gibailongdong, Dieyunyandong, Dziyundong in Baiyundong. Skupna dolžina rovov je $1.478 \mathrm{~m}$, razdelitev intervalov na $10^{\circ}$.

We do not have a large amount of data on directions and dips of beds, as most caves developed in thicker-bedded carbonate rock. For the most part, the beds are subhorizontal and/or dip at a fivedegree angle. All four caves formed in Lower Permian limestone.

\section{Hydrology}

During our two-week visit to China's Yunnan Province, we also investigated the composition of karstic water, including underground water in five caves in the Shilin Stone Forest area and four in the Puzhehei area. We also took two samples from the Quing Shui River, which flows to Puzhehei Lake, and the water from a spring that flows directly into the lake. We planned two tracing experiments through the vadose zone of two caves in the Shilin (Stone Forest) area, but were unable to carry them through due to the dry period prior to our arrival and during our stay in China. Instead, we took a closer look at the relief above the caves and at the conditions in the lower- lying caves and determined suitable points for tracer injection and the sample-taking area for percolating water in the caves. We roughly determined the amounts of fluorescent tracer (uranine, rhodamine) necessary, along with the method of injection. The tracer experiments will be carried out in suitable weather and hydrologic conditions by our Chinese colleges under the guidance of Liu Hong. 
We also visited the area surrounding Guangnan, where we observed the Mu Mei karst spring, which has a mean flow of $5.9 \mathrm{~m}^{3} / \mathrm{s}$, a minimal flow of $0.8 \mathrm{~m}^{3} / \mathrm{s}$ and a maximal flow of $13.7 \mathrm{~m}^{3} / \mathrm{s}$. Because drinking and irrigation water is scarce in the winter months, a dam was constructed 200 years ago and renovated in 1950. Thus, a larger amount of water is retained in the accumulation period for dry spells; however, the amount no longer suffices, which is why they wish to build a new dam. As we noticed large hollows on the border and on the bottom of the lower and middle parts of the valley, we advised that detailed hydrological research of the area be carried out. We expect that the possibility of a significant outflow of water from such an accumulation would be high.

We observed that the water distribution system in certain villages lack a water source nearby in the vicinity of Guangnan. Due to this, rainwater is collected from roofs and directed into reservoirs built in courtyards. In these cases the locations of such reservoirs is very important, as pollution originating from higher locations can contaminate the collected water. It is commendable that they have considered sand filters for filtering the rainwater before it is collected in the reservoir. This method of water distribution is supported financially by the local administration. All higher-situated karstic areas without karstic springs are water-deficient, as nearly $97 \%$ of the Guangnan area is karstic.

In the course of taking water samples in the field, we measured the temperature $(\mathrm{T})$, specific electric conductivity (SEC), $\mathrm{pH}$ and in some places also the content of dissolved oxygen in the water $\left(\mathrm{O}_{2}\right)$. The measurements were carried out using the Multiline P4 WTW apparatus with the appropriate probes. We completed the following chemical analyses in an improvised laboratory: carbonate, calcium $(\mathrm{Ca})$ and magnesium $(\mathrm{Mg})$ content, titrimetrically by standard methods (Standard Methods 1992) and semi-quantitatively $\mathrm{SiO}_{2}$ and sulphate content (colorimetrically and/or turbidimetrically).

\section{Water Characteristics in the Shilin (Stone Forest) Area}

Due to relatively dry weather, dripping of percolated water was rare and with small flow rates in the Shilin area. In the cave Shimatandong, with a cave ceiling thickness of only up to 10 metres, we were able to collect a sufficient sample of water from three drippings - sample $\mathrm{M}_{0}$ (see Tab.).

In Gibailongdong Cave, whose exit is in the middle of the village with the area above it partially settled, we took a sample of percolating water dripping onto a small flowstone mound - $\mathrm{N}_{0}$ and a sample of water in the pool directly next to it - Na.

The dripping in Dieyunyandong was so weak that we were not able to take a sample of percolated water. The dripping was also weak in Dziyundong Cave, but we were nevertheless able to take a sample from a small pool with water dripping slowly into it - Oa. In the direct vicinity we observed a river disappearing first into a shorter cave, then flowing across a small valley to a cave opening in its slope. The river then sinks, but is again accessible at the bottom of a larger doline. This shows that this karst is well hollowed out and that water flows rapidly through it. We took a sample of the water at the outflow from the mentioned small cave - P.

In 1996, 1997 and 1998, we took samples from Baiyundong Cave in Naigu Shilin. In the first year we took the samples in July and the next in September, which was still during the rainy season when drippings were numerous and ample. The flow rate of the stream $\mathrm{L}$ was estimated at several litres per second. In November 1998 there was a distinct dry period and we were not able to take 
samples of percolated water. In October 1999 the drippings were slight; dripping $\mathrm{G}$ was not active at all. We estimated the stream flow rate $\mathrm{L}$ at the beginning of the cave at $0.1 \mathrm{l} / \mathrm{s}$, although it is likely that it was higher, because a portion of the water from the initial lake is led to the depths through a pipe and to a flowstone mound, which is usually without water inflow.

We collected percolated water $\left(\mathrm{G}_{0}-99, \mathrm{H}_{0}-99, \mathrm{~J}_{0} *_{-}-99\right)$, the water from a gour near the gours I (Igour) and from the stream flowing through the cave $\left(\mathrm{L}_{1}-99, \mathrm{~L}_{2}-99\right)$ at the beginning and at the end of the cave. The deposition of flowstone from the stream is clearly visible on the water surface.

\section{Water Characteristics in the Puzhehei Area}

We saw a number of caves in fengs (karst towers) in the level of the lake in the Puzhehei area. We took the first sample $\left(\mathrm{R}_{0}\right)$ of percolated water at the exit of a cave around 10 metres long, directly, to prevent sample aeration. In the next cave, we took percolated water $\left(\mathrm{S}_{0}\right)$ dripping to a collector 2.5 metres lower down and from a small dripping deeper into the cave $\left(\mathrm{T}_{0}\right)$. We went into the next cave - by boat - taking a sample at the beginning $\left(\mathrm{Z}_{1}\right)$. We continued through a dry section of the cave; further on, the path ran alongside the stream. We took a sample of this water before exiting the cave $\left(Z_{2}\right)$. Further on, the stream ran from the cave through a pipe installed to prevent the water from flooding the lower exit section of the cave. In November 1998, during the dry period, when we visited the cave for the first time in the reverse direction, we did not notice any outflow of water; it seemed that the hydrological conditions were completely different.

On the way to the lake, that is, on the Quinshui river in the opposite direction of the flow, we carried out a number of measurements and took some samples before Puzhehei village $\left(\mathrm{X}_{1}\right)$ and lower, behind a village of Xianrendongminsu $\left(\mathrm{X}_{2}\right)$.

\section{Table 1.}

\begin{tabular}{|c|c|c|c|c|c|c|c|c|}
\hline Sample & $\begin{array}{l}\mathrm{T} \\
{ }^{\circ} \mathrm{C} \\
\end{array}$ & $\begin{array}{c}\mathrm{SEC} \\
\mu \mathrm{S} / \mathrm{cm} \\
\end{array}$ & $\overline{\mathrm{pH}}$ & $\begin{array}{c}\text { Carbonates } \\
\text { meq } \Lambda\end{array}$ & $\begin{array}{l}\mathrm{Ca}^{2+} \\
\mathrm{meq} / \mathrm{l}\end{array}$ & $\begin{array}{l}\mathrm{Mg}^{2+} \\
\text { meq } / 1\end{array}$ & $\begin{array}{c}\text { Total hardness } \\
\text { meq } /\end{array}$ & $\mathrm{Ca} / \mathrm{Mg}$ \\
\hline Ho - 99 & & 591 & 7.88 & & 5.12 & 1.44 & 6.56 & 3.6 \\
\hline I*0 - 99 & 16.9 & 524 & 7.94 & 5.5 & 4.36 & 1.56 & 5.92 & 2.8 \\
\hline$L_{1}-99$ & 16.4 & 582 & 7.29 & 6.52 & 5.36 & 1.36 & 6.72 & 3.9 \\
\hline$L_{2}-99$ & 16.5 & 455 & 7.5 & 4.86 & 3.72 & 1.24 & 4.96 & 3 \\
\hline$I_{\text {gour }}-99$ & 16.7 & 330 & 8.37 & 3.46 & 2.16 & 1.76 & 3.92 & 1.2 \\
\hline Mo & & 392 & 8.52 & 4.18 & 2.2 & 2.2 & 4.4 & 1 \\
\hline No & 17.4 & 783 & 8.24 & 4.94 & 6.88 & 0.48 & 7.36 & 14 \\
\hline $\mathrm{Na}$ & & 480 & 7.97 & 3.5 & 3.84 & 0.48 & 4.32 & 8 \\
\hline $\mathrm{Oa}$ & 17 & 436 & 8.12 & 3.42 & 4.32 & 0 & 4.32 & \\
\hline $\mathrm{P}$ & 19.1 & 444 & 8.09 & 4.78 & 3.44 & 1.41 & 4.85 & 2.4 \\
\hline Ro & & 925 & 7.47 & 10.5 & 5.92 & 4.4 & 10.32 & 1.3 \\
\hline So & 18.6 & 605 & 8.17 & 8.36 & 4.48 & 2.4 & 6.88 & 1.9 \\
\hline To & & 462 & 8.37 & 4.94 & 4.32 & 0.96 & 5.28 & 4.5 \\
\hline Uo & & 800 & 7.83 & & 4 & 5.2 & 9.2 & 0.8 \\
\hline Vo & & 597 & 8.63 & & & & 7.68 & \\
\hline$z_{1}$ & 17.8 & 480 & 7.52 & 5.17 & 3.84 & 1.24 & 5.08 & 3.1 \\
\hline$Z_{2}$ & 16.8 & 394 & 7.7 & & 3.56 & 0.72 & 4.28 & 4.9 \\
\hline$Y$ & 21.8 & 378 & 8.3 & 4.14 & 2.32 & 1.92 & 4.24 & 1.2 \\
\hline$x_{1}$ & 21.8 & 267 & 7.89 & 2.87 & & & & \\
\hline$x_{2}$ & 21.8 & 269 & 7.63 & 2.8 & 2 & 0.88 & 2.88 & 2.3 \\
\hline
\end{tabular}




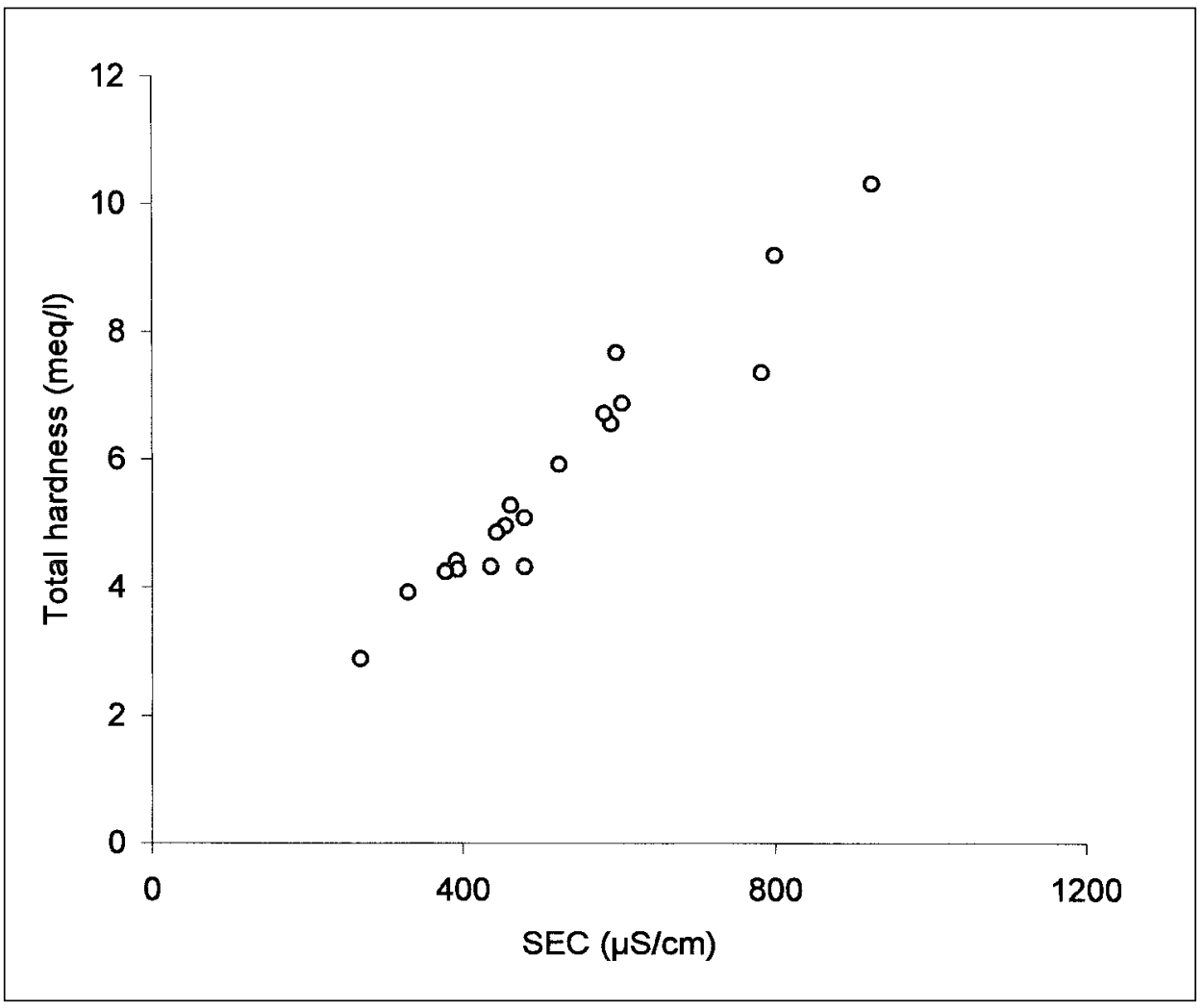

Fig. 2: Relation between total hardness of water and specific electric conductivity. Sl. 2: Odnos med celokupno trdoto vode in specifično električno prevodnostjo.

We took a sample of completely different water (Y) flowing from springs on the opposite side from behind the fengzong and running into the lake and/or river.

At the end of our visit in the area, we took two additional water samples from "old caves", higher in the fengzong, percolated, sample $\mathrm{U}_{0}$ and from gours $(\mathrm{Va})$.

The results of physical measurements and chemical analyses are presented in Table and in Fig. 2.

\section{Conclusions drawn from measurements and results of analyses}

The highest content of carbonate and calcium was measured in percolated water from caves in the Puzhehei area. That water is saturated and deposite flowstone. Samples of water in gours and from the stream at the end of Baiyundong Cave indicate flowstone deposition with lower carbonate and calcium values and smaller $\mathrm{Ca} / \mathrm{Mg}$ proportions. High $\mathrm{SEC}$ values in comparison with carbonate and total hardness, especially in Gibailongdong Cave, very probably reflect polluted percolated water. This could only be confirmed by additional analyses, such as chloride, nitrate, sulphate, phosphate and other content. 
Lake water analyses demonstrated the lowest values of carbonate, calcium and magnesium and a lower value of dissolved oxygen in the sample from the lower part of the flow. Thus sample $\mathrm{X}_{2}$, after both villages have polluted it, contains only $4.4 \mathrm{mg} \mathrm{O}_{2} / 1$, which means it was only $59 \%$ oxygensaturated. In the upper section, above the villages, sample $\mathrm{X}_{1}$ contained $6.3 \mathrm{mg} \mathrm{O}_{2} / 1$, which signifies $84 \%$ oxygen saturation.

Water flowing from the spring behind the feng (karst tower) - Y has a completely different composition. The water in the cave there deviates from the spring and from water in the lake, which is obvious in almost all the measured parameters. Some mixing of the water from both sources is possible, as is inflow of percolated water from the relatively high feng, as we noted the highest values of carbonate and calcium content in percolated water. However, we cannot base an explanation of these differences on the performed measurements and analyses.

\section{Morphology}

\section{Tower karst of Puzhehei region}

Puzhehei is the name of the village and of the lake, meaning in the language of Yi minority "The lake, rich with crabs and fishes", in Southeast of Yunnan, the county of Quibei. It lies $24^{\circ} \mathrm{N}$ and $104^{\circ} \mathrm{E}$, at the altitude of $1450 \mathrm{~m}$ (according to the map $1: 50000$ ), the mean year temperature being $16^{\circ} \mathrm{C}$ and $1100 \mathrm{~mm}$ of precipitation.

From alluvial plain, partly marshy and partly cultivated (rice fields), individual limestone hills - towers and cones, are rising, completely separated from each other. This is typical example of tower or cone karst, fenglin (feng $=$ peak, lin $=$ forest) by Chinese terminology and classification (Yuan et al. 1991). The region occupies about $100 \mathrm{~km}^{2}(10 \times 14 \mathrm{~km})$ and includes over 150 towers and cones (mogotes), fengs in Chinese, of the relative height between $50-200 \mathrm{~m}$.

North of Puzhehei is slightly higher lying karst country of cockpit type or fengcongwadi (literal meaning is "peak cluster - depression"). As the name shows karst towers are not separated (which is the fenglin characteristic) but they have common base (fengcong). Between them are close depressions - (star shaped) dolines called cockpit. This cockpit karst is about $20 \mathrm{~km}$ long and $7 \mathrm{~km}$ large, bordering the impermeable rocks terrain. South and east of Puzhehei there is normal (erosion) relief again. The border between carbonate and non-carbonate rocks is of tectonic origin and it is nearly strait line in long distance.

Waters running on cockpit karst from the north lying impermeable rocks sink on the contact and resurge in karst springs on its southern border. That is on the contact with Puzhehei tower karst, thus feeding its rivers, marshes and lake Puzhehei. Some water is running from the nearby normal relief directly to the Puzhehei alluvial plain. Runoff from the Puzhehei karst is completely over the surface. Water runs as a river through impermeable southern and south-eastern margins and finally discharged into the South China Sea.

The position of Puzhehei karst is essential for its morphology. Recent findings (Mangin \& Bakalowicz 1990; Sweeting 1995) show that there are two main factors important for the development of tower karst: piezometrical level practically at the surface and slow, long and constant uplifting of the terrain. It is not possible to state that the terrain is being uplifted on the base of a short visit only, but distinctive lithological boundaries along tectonical lines are proving that tectonic played important role in the development of the region. Puzhehei karst is surrounded by impermeable rocks forming 
hydrogeological barrier. So it is possible to imagine that the piezometric level was relatively constant (at the surface of alluvial plain) during long geological periods. It had to be long period of equilibrium between the slowly uplifting of terrain and deepening of the surface by corrosion. This was the base for the development of such tower karst or fenglin, that is "peak forest".

Lowering of the surface and simultaneous uplifting of the surface is also proved by older (fossil) caves, higher in the towers. The examples are caves Xianrendong high in the slope of the feng above the village Xianrendongminsu and Cangshandong, $30 \mathrm{~m}$ above the foot of Cangshan tower, south of the mentioned village, which we have visited too. They are richly ornamented by flowstone. Flowstone in the entrances and its remnants out and under the cave entrances can indicate that these caves are remnants of old caves, the entrances being formed by the recessing of slopes. Such caves are numerous, but even more are so called foot caves (jaodong). They developed and are still forming nowadays in the foot of towers, in the alluvial plain level, that means in the piezometric level or immediately underneath.

\section{Caves in the Puzhehei tower karst}

Cone bases are intermeshed with the characteristic foot caves. As a rule, the caves comprise a relatively dense network of passages; the diameter is up to five metres, and most caves are small and seem to have developed from anastomoses between beds. They are predominantly composed of level passages in various planes. The bottom of the lowest accessible caves are covered with water, while passages one to three metres above the water table are dry and frequently almost entirely filled with flowstone and sediment. Water caves form cavities in the bases of those singular cones that are not entirely surrounded by water. The rocky relief of water passages with medium-sized scallops and ceiling cups indicates their formation by a slower water flow which occasionally floods them. Below-sediment notches can also be found near bedding-planes. The shape of and the sediments in dry, higher passages both point to a number of phases in their development. Above sediment channels and along sediment wall notches, there are frequent signs of the passages being filled with sediment. The passages in one of the caves are three metres above the mean water table level; we collected sediment samples for palaeomagnetic investigation. The question of reading various cave development periods and the duration of each period by small differences in height has emerged, as caves 40 metres or higher above the water level are frequently old caves. Their shapes - larger and especially higher passages with large ceiling cups and an absence of signs of distinct water flow point to different formation circumstances, namely formation by a prolonged and slow water flow, as can be observed in deeper flooded karst areas. Large stalactites and flowstone mounds are usual in these caves. Belts of flowstone and stalactites 10 and more metres long, the only remains of former passages, are located in front of cave entrances. Did these caves form before the karst relief disintegrated into cones? A wider regional investigation of various caves in traverse and longitudinal sections will be necessary to answer this question.

\section{Pillar Peaks in the Shilin}

The rocky relief in the three selected parts of stone forest areas has been described (Slabe 1998) and the basic significance pointed out regarding research into Stone Forest development. There are, of course, many more and different Lunan forests. These forests lie in valleys or on small hills; the pillars within them stand in groups or are spread evenly across larger areas. Groups can be composed of large pillars with hardly any space between them, or of narrow and separately standing pillars. 


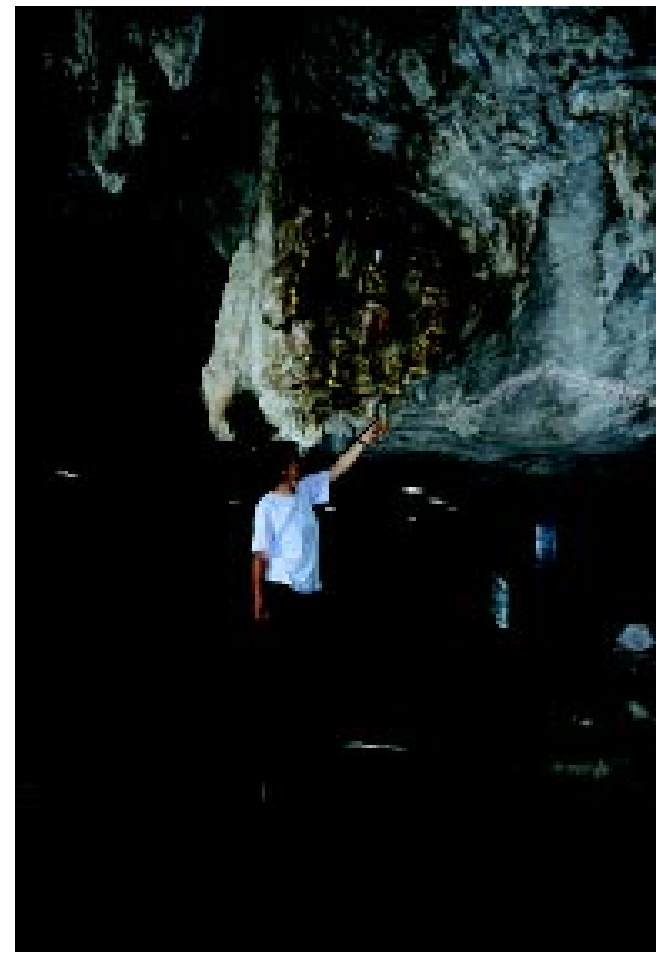

Fig. 3: Water sampling in Guangyindong Cave (Puzhehei region) (Photo J. Kogovšek). Sl. 3: Vzorčevanje vode vjami Guangyindong (področje Puzhehei) (foto J. Kogovšek).

Fig. 4: View of Puzhehei "fenglin" (tower karst). The village of Xianrendongminsu in foreground (Photo S. Šebela).

Sl. 4: "Fenglin" (stolpasti kras) v Puzhehei. Spredaj je vas Xianrendongminsu (foto S. Šebela).

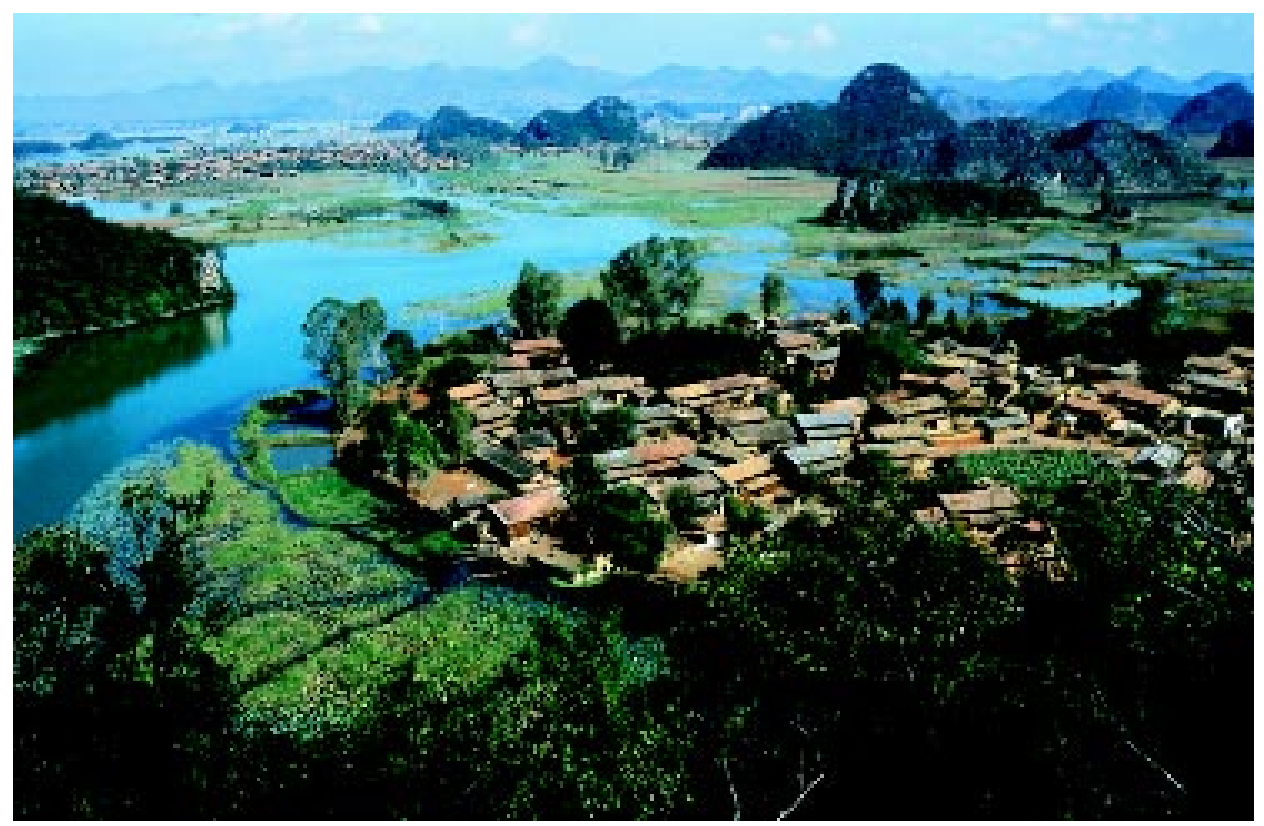




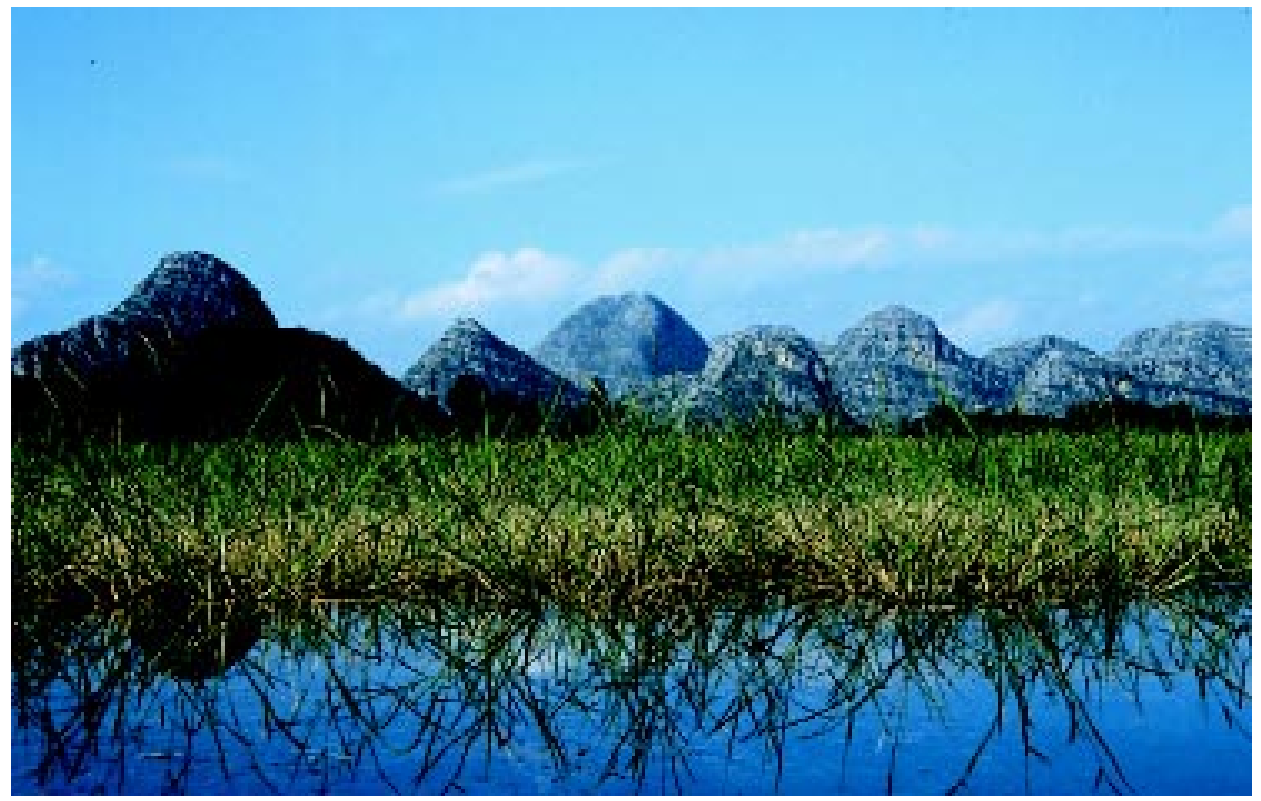

Fig. 5: "Fengs" (towers and cones) of Puzhehei karst area (Photo S. Šebela). Sl. 5: "Fengi" (stolpi in stožci) na krasu Puzhehei (foto S. Šebela).

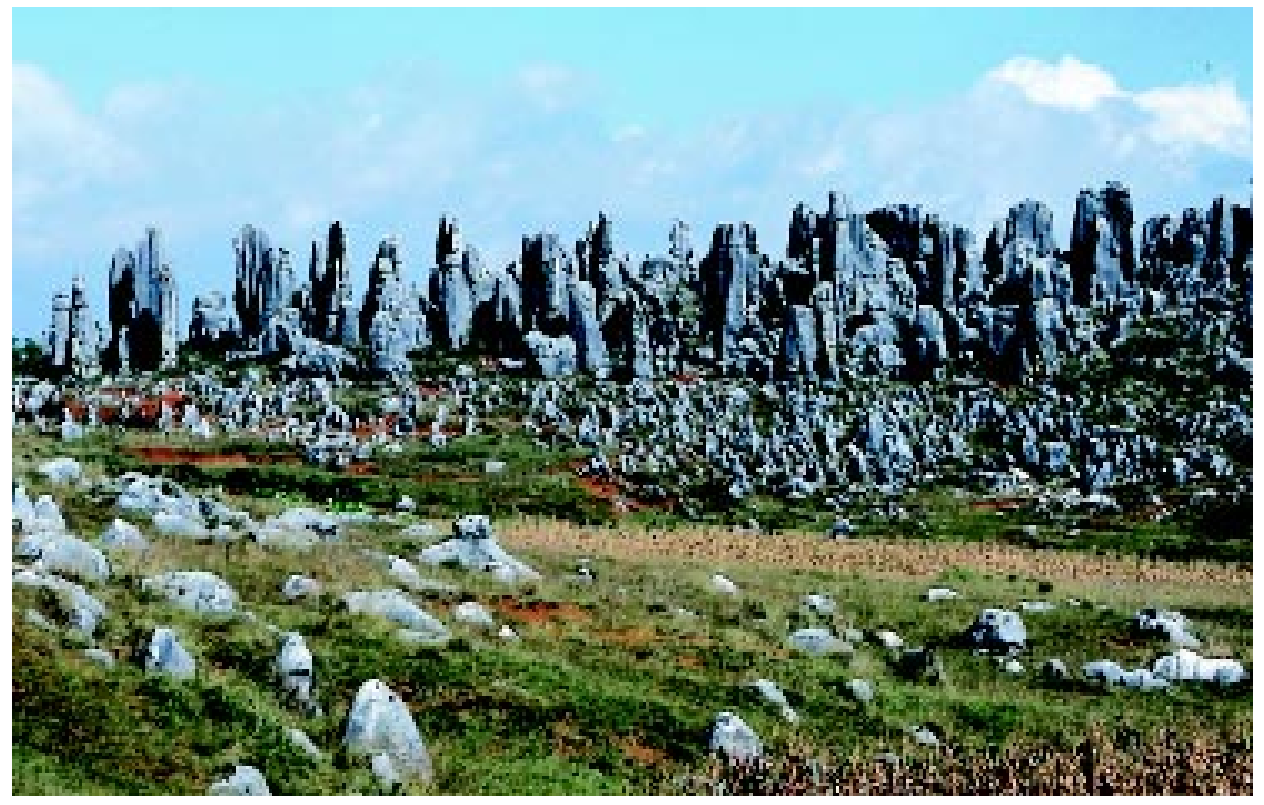

Fig. 6: One of the numerous "shilins" in the Shilin county. (Photo T. Slabe). Sl. 6: Eden izmed številnih "shilinov" v okrožju Shilin (foto T. Slabe). 


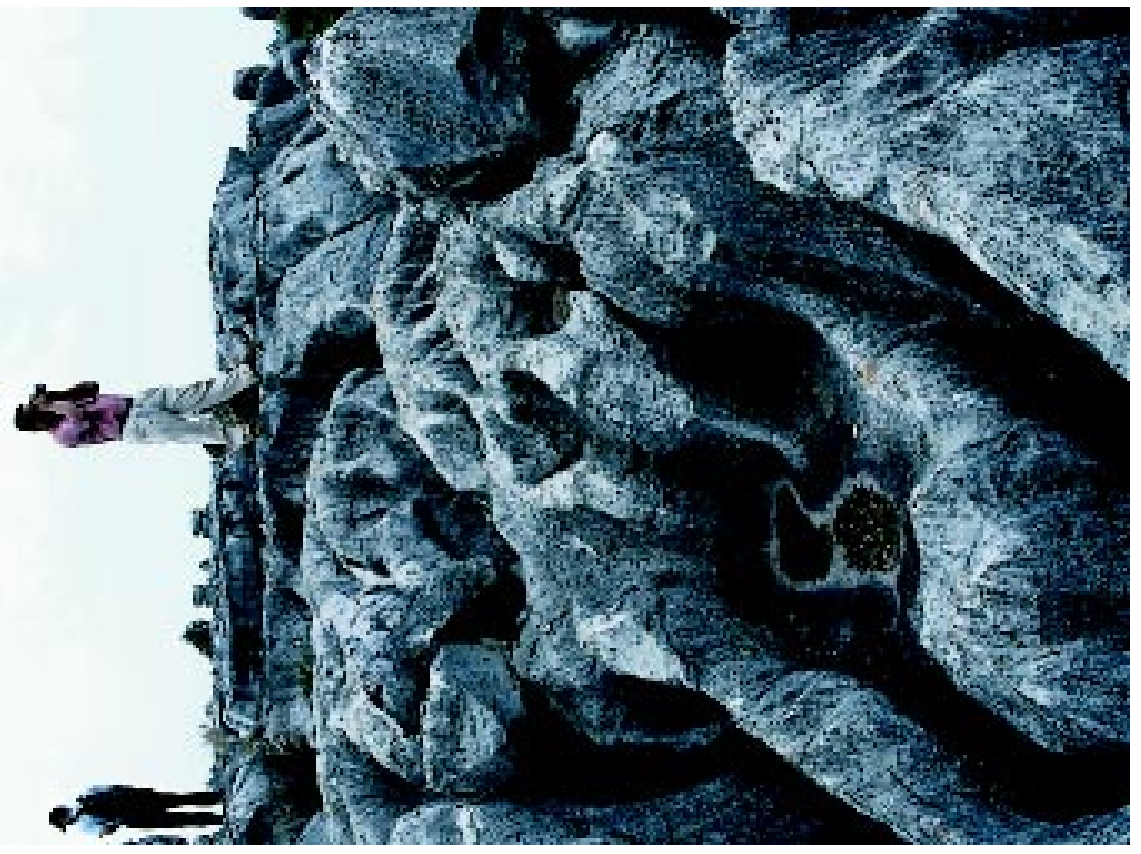

$\frac{2}{\frac{\pi}{2}} \stackrel{0}{0}$

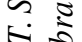

$\therefore \stackrel{2}{2}$

$\frac{2}{2} \overbrace{0}^{2}$

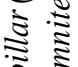

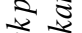

$\frac{2}{2} \stackrel{-1}{2}$

히

$5 \sqrt{2}$

2)

5.

记

$5=$

交:

च

त)

z

$\dot{\infty} \dot{\infty} \frac{\vec{\sigma}}{\frac{0}{\sigma}}$

$\therefore \rightarrow$

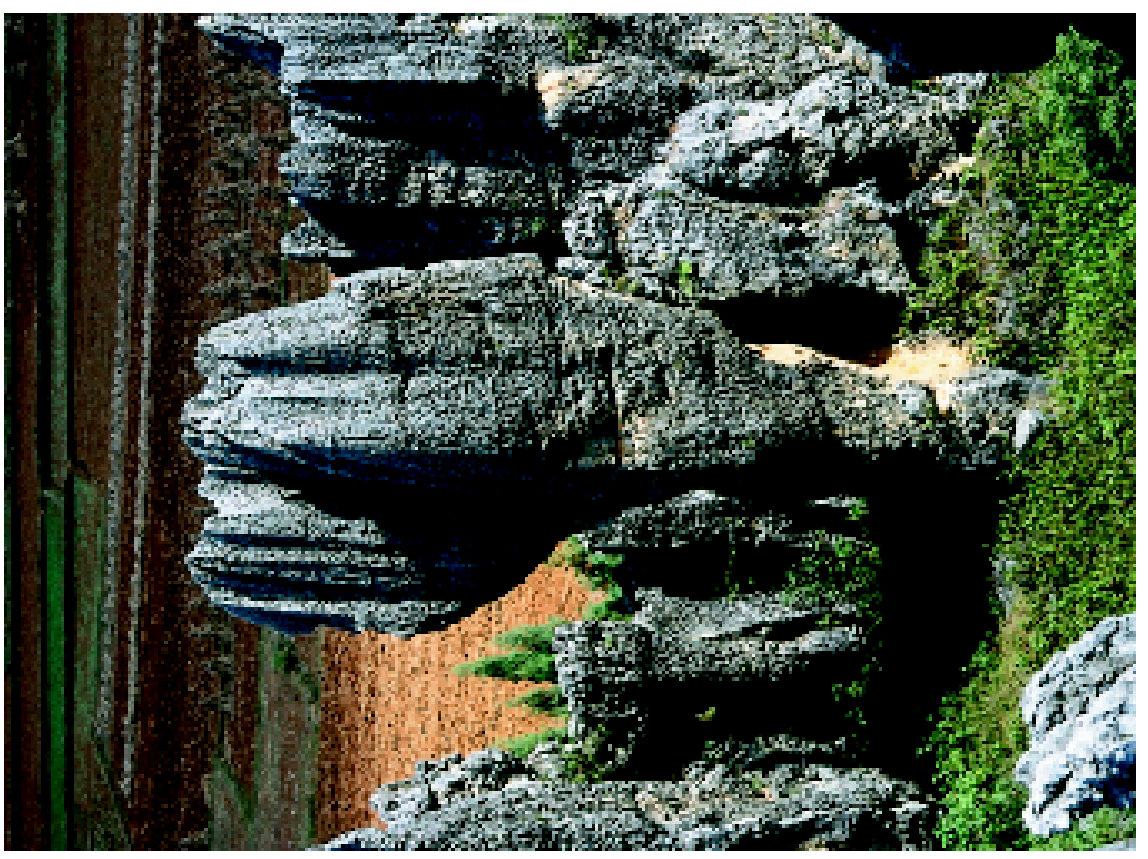

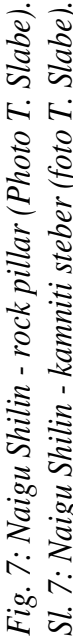


The shape of the pillars mirrors the characteristics of the composition and disintegration of the rock and its development. Our intention is to describe the various types of stone forests, their position and shape, their rock and tectonic characteristics, the shapes of pillars and their rocky relief, of course in connection with descriptions of their growth and development.

This time, our interest was directed towards the shapes of the peaks on various pillars. Our findings were supplemented by exposing to rainfall various plaster shapes, both bare and soil-covered. It is important to recognise in the shape the portion of stone forest heritage.

The peaks of stone pillars can be divided into two basic types: pointed or blade-shaped, variously incised peaks, and peaks with upper planes of different sizes, inclinations and incisions. The main factors influencing pillar shape are the formations beneath soil and sediments. This is determined by soil and sediment seepage characteristics for water, by the characteristics of the rock, and by the way the rock disintegrates on the surface. Rock composition and incision again primarily precondition these factors.

Song Linhua and Liu Hong (1992) divided rock teeth into groups by their resemblance to human teeth. I classify them as pointed, blade-shaped and rock teeth of different sizes of upper planes. This classification is similar to the one for pillar peaks. Many are already disintegrated when they appear on the surface, frequently with subsurface rock forms. This is important for their further formation, especially if these forms are large. Small channels first appear on the smooth and inclined planes. In the beginning, and on rock composed of small and uniformly large particles, the channels are small; they reach their mature size later. Subsurface channels are also transformed. The orifices of vertical channels enlarge, and the walls become covered in small channels. Rainwater forms small recesses in the elongated and hemispherical notches that develop on the longer-lasting level of soil surrounding the teeth. On teeth with level upper surfaces, subsurface channels and hollows frequently develop. As the level of soil surrounding the teeth lowers, soil remains only in hollow and overgrown spaces. Subsurface rock forms are preserved on pillar peaks. Recesses may develop from them, or the rainwater may break down the edges of the small hollows and create funnel-formed wall channel orifices. Such channels also develop on walls beneath subsurface channels. The flat pillar peaks are preserved primarily in those places where level rock beds are falling apart. Such peaks preserve flat or slightly inclined upper surfaces that can be covered with solution pans. Hemispheric channel orifices develop on the edges and cover the pillar walls.

The flat pillar formation described was also verified by the experiment with plaster. As mentioned, such peaks are cut up in a characteristic way when covered by subsurface rock forms or when tubes between beds develop along bedding-planes. The upper planes of more inclined wide pillars are covered with a network of smaller and larger channels and flat surfaces on which water running from the channels accumulates. The points sharpen; the same is true for blade-shaped peaks, which frequently develop from rounded scratches on subsurface teeth. They maintain a unified bladeshaped appearance if subsurface rock forms did not incise into them or if the disintegration is not defined by rock characteristics. Small channels cut into it. The uneven rock composition causes the development of recesses. 


\section{Baiyundong - the cave beneath the Shilin (Stone Forest)}

Baiyundong Cave is located in the Naigu Stone Forest and is 380 metres long. It lies few ten metres below the surface. A stream flows through it. It is open for visitors.

The cave is a network of level passages. The largest central passage has a diameter of up to 10 metres. The ceiling is mostly flat and has a central ceiling channel running across it. There are small scallops on the walls and above-sediment channels on the ceiling. The remains of cave sediments can be divided into three groups. Beds of pebbles and fine-grained sediment lie in the middle section of the passages, with a flowstone encrustation formed over them. We collected samples of finegrained sediment for palaeomagnetic investigation and some flowstone in order to determine its age. Predominantly pebble sediment in small amounts is preserved in the upper section of the passages; this sediment was also preserved in above-sediment channels. Higher up and in some places in the above-sediment channels, a fine-grained sediment was preserved.

We were able to deduce the periods of the development of the cave from its shape, the rocky relief and the sediments preserved within it.

We theorise that the cave began to form as bedding-plane anastomoses. The main tubes grew into passages. Most of the cave was then filled with sediments, which indicates alternating rapid water flows and flooding of the cave. In a typical flood period, the cave would fill up with fine grainy sediment. Water would flow over the sediment for a relatively long period, while levelling the ceiling and cutting a meshwork of above-sediment anastomoses with a central above-sediment channel into it. Rapid water flows, which also transported pebbles, would carry most of the finegrained sediment from the cave. They would also deform above-sediment channels. The pendants between them are sharp, and only singular channels have a preserved omega-shaped cross section. On the walls are small scallops, signs of rapid water flows.

\section{ACKNOWLEDGEMENTS}

We would like to express our gratitude to the Chinese and Slovene Ministries for Science, which made our research possible; to the Shilin (Stone Forest) management, especially to the director and his assistant Mr. Tao; to the management of the tourist office in Quibei; and to Mr. Lu and the Guangnan county governor and his co-workers.

We especially wish to thank our Chinese colleagues Liu Hong, Chen Xiaoping, Huang Chuxing and Zhan Fan for their kindness, selfless assistance and companionship. We will always look forward to meeting and co-operating with them in the future.

\section{REFERENCES}

Mangin, A. \& M. Bakalowicz, 1990: Le karst conique: sa genèse à partir de l'example du karst du sud de la Chine.- C. R. Acad. Sci. Paris, t. 310, Série II, p. 301-307, Paris

Slabe, T., 1998: Rock Relief of Pillars in the Lunan Stone Forests (In: South China Karst 1).- p. 5167, Založba ZRC 19, Ljubljana

Song, L. \& H. Liu, 1989: Cockpit karst and Geological structures in South Yunnan, China.- $3^{\text {rd }}$ Multidisciplinary Conf. on Sinkholes, Florida, p. 377-384 
Song, L. \& H. Liu, 1992: Control of geological structures over development of cockpit karst in South Yunnan, China.- Tübingen Geographische Studien, 109, 57-70, Tübingen

Sweeting, M. M., 1995: Karst in China.- Springer, pp. 265, Berlin etc.

Yuan, D. \& D. Zhu \& J. Weng \& X. Zhu \& X. Han \& X. Wang \& G. Cai \& Y. Zhu \& G. Cui \& Z. Deng, 1991: Karst of China.- Pp. 224, Geological Publishing House, Beijing

\section{JUŽNO KITAJSKI KRAS 1999 PREDHODNE RAZISKAVE V YUNNANU}

\section{Povzetek}

Krasoslovci z yunnanskega geografskega inštituta in sodelavci Inštituta za raziskovanje krasa ZRC SAZU že več let uspešno sodelujemo. Izsledke dosedanjih raziskovanj smo zbrali tudi v knjigi South China karst. Pridobili pa smo nov projekt Primerjava klasičnega slovenskega krasa $\mathrm{z}$ yunnanskim, ki ga denarno omogočata kitajsko in slovensko Ministrstvo za znanost. V okviru tega projekta smo v oktobru 1999 izvedli prvi del terenskih raziskav, o katerih tokrat poročamo. Nadaljevali smo z raziskavami lunanskih kamnitih gozdov (shilinov) in jam pod njimi, začeli smo raziskovati stolpasti (fenglin) kras v Quibeiu in proučili smo možnosti za razširitev našega raziskovanja na jugovzhodni del province, kjer je tudi izredno zanimiv “cockpit” (fengcong) kras s številnimi jamami. V prihodnjih letih pa načrtujemo tudi raziskovanje gorskega krasa na severu province.

Zahvaljujemo se kitajskemu in slovenskemu Ministrstvu za znanost, ki omogočata naše raziskovalno delo, upravi Shilina (Kamnitega gozda), še zlasti gospodu direktorju in njegovemu namestniku gospodu Tao, vodstvu Turističnega biroja v Quibeiu in gospodu Lu-ju ter gospodu guvernerju okrožja Guangnan in njegovim sodelavcem.

Še posebej pa bi se radi zahvalili za prijaznost, požrtvovalnost in prijateljstvo našim kitajskim sodelavcem Liu Hong-u, Chen Xiaoping-u, Huang Chuxing-u in Zhan Fan-u. Vsakokrat se veselimo srečanja in dela z njimi. 